HORTSCIENCE 25(4):433-435. 1990

\title{
Alteration of Poinsettia Stem Anatomy by Growth-retarding Chemicals
}

\author{
Gary L. McDaniel, Effin T. Graham, and Kathleen R. Maleug \\ Department of Ornamental Horticulture and Landscape Design, \\ University of Tennessee, P.O. Box 1071, Knoxville, TN 37901 \\ Additional index words. Euphorbia pulcherrima, growth substances, paclobutrazol, \\ chlormequat, ancymidol, uniconazole, stem anatomy
}

Abstract. The effects of growth-retarding chemicals on stem anatomy were compared on poinsettia (Euphorbia pulcherrima Wind. 'Annette Hegg Dark Red'). Micrographic examinations revealed that secondary walls of nonsclerotic phloem fiber cells were either completely or greatly reduced by retardant treatment. Wall thickening of phloem fiber cells was eliminated by paclobutrazol foliar sprays at $25 \mathrm{mg} \cdot 1$ iter ${ }^{-1}$. Fiber cell development was reduced, but not eliminated, by sprays of chlormequat and ancymidol at standard rates, while the triazole uniconazole at $10 \mathrm{mg} \cdot \mathrm{liter}^{-1}$ permitted only limited fiber wall thickening. Chemical names used: (2-chloroethyl)-trimethyl ammonium chloride (chlormequat); $\alpha$-cyclopropyl- $\alpha$ - (4-methoxyphenyl) -5-pyrimidine methanol (ancymidol); (E)-( $p$-chlorophenyl)-4,4-dimethyl-2-(1,2,4-triazol-1-yl-1-penten-3-ol (uniconazole): and $\left(\mathrm{R}^{*}, \mathrm{R}^{*}\right)-\beta$-[(4-chlorophenyl)methyl]- $\alpha$-(1,1-dimethylethyl)- $1 \mathrm{H}$ $1,2,4$,triazole-1-ethanol (paclobutrazol).

A major production problem with the selfbranching poinsettias (Hegg and Gutbier cultivars) is their development of thin stems that are prone to bending and breakage when handled or shipped (Larson et al., 1978). Chlormequat has been the standard growthretarding chemical used in commercial production of poinsettia for many years (Lindstrom and Tolbert, 1960). Poinsettia stems treated with chlormequat had less developed and thinner walled phloem fibers than controls (Crittendon and Kiplinger, 1969). No effects of other growth-controlling chemicals on stem anatomy or strength of poinsettia have been reported. Ancymidol (a substituted pyrimidine) and paclobutrazol (a triazole) are more recently developed chemicals with label clearances for use on poinsettia (Larson et al., 1978; McDaniel, 1986). Uniconazole is a recently discovered triazole that has shown growth-controlling effects on several ornamental crops (Banko and Stefani, 1988; Barrett et al., 1986; Mansour and Poole, 1987; Sterrett, 1988).

Microscopic studies of retardant-treated plants have been confined primarily to the apical region of the stem. The chemicals retard stem elongation by limiting cell division

Received for publication 22 May 1989. This research was supported in part by funds from the Fred C. Gloeckner Foundation. The cost of publishing this paper was defrayed in part by the payment of page charges. Under postal regulations, this paper therefore must be hereby marked $a d$ vertisement solely to indicate this fact. and extension in the subapical meristematic zone of the stem (Sachs et al., 1960). Diameters of basal internodes in treated plants often were greater than in nontreated specimens (Greulach and Haesloop, 1954; Larson and Kimmons, 1972; Sachs and Kofranek, 1963). Vascular cambium continued to divide in retardant-treated stems, and cambial parenchyma accumulated up to twice the width in nontreated plants of the same age, while cell differentiation was delayed (Shafshak et al., 1976).

Thickening of retardant-treated stems could be inferred to result in sturdier plants. However, phosphon-treated stems of Lilium longiflorum Thunb. exhibited thin-walled, enlarged fiber cells next to the cortex, whereas untreated lily stems displayed a layer of small, thick-walled, sclerenchyma cells in that same region (Cathey and Stuart, 1961). Treated lily stems could not support the weight of flowers. Maleic hydrazide has been shown to inhibit lignification of fiber cells from cambial tissue of woody species grown in vitro (Jacquiot, 1953). Phloem parenchyma cells of daminozide-treated marigold were reported to have larger lumens with thinner walls (McConnell and Struckmeyer, 1971).

The purpose of this investigation was to determine the effects of several growth-retarding chemicals on stem structure and development of a self-branching poinsettia cultivar.

Single rooted cuttings of 'Annette Hegg Dark Red' (AHDR) were planted on 31 Aug. 1988 into 1.6-liter pots containing Pro-Mix $\mathrm{BX}$ [1 peat : 1 perlite : 1 vermiculite (by 
the next in series.

Stem measurements. Lateral stem lengths were considerably shortened by all chemicals by the 2 nd week following treatment (Table 1). However, cross-sectional areas were not increased by chemical treatments as expected, but rather were equal to or smaller than controls.

Stem anatomy. Fiber development of poinsettia stems was completely inhibited by paclobutrazol treatment at $25 \mathrm{mg} \cdot$ liter $^{-1}$ (Fig. 1). When compared with the control (Fig. 1 $\mathrm{A}$ and $\mathrm{C}$ ), the ring of tissue occupied by xylem elements was much reduced (Fig. 1B) and definition of xylem fiber and xylem parenchyma cells was uncertain (Fig. 1D) in the paclobutrazol treatment. Phloem fiber cells located in narrow bands between phloem and cortex were characterized by thickened but nonsclerotic walls enclosing lumens in control tissue (Fig. 1C). In the corresponding region of sections that received paclobutrazol, however, cell wall thickenings were absent and thin walls enclosed large lumens (Fig. 1D). These histological effects of paclobutrazol were evident from 4 weeks through 10 weeks post-treatment.

Stem anatomy of plants treated with ancymidol, uniconazole, or chlormequat was intermediate between paclobutrazol and control (not shown), with some phloem fibers and xylem fibers persisting with clearly thickened walls. Uniconazole-treated stems exhibited very few thickened phloem fiber cells in bundle caps.

Growth retardants, particularly the triazoles, suppressed development and differentiation of poinsettia stem cells some distance from the apical meristem. Phloem bundle caps and interfascicular supporting tissues did not differentiate by the time bracts were formed in poinsettia plants treated with paclobutrazol and, therefore, were structurally weaker than controls. Absorption of paclobutrazol through the epidermis of stems during foliar applications, as reported by Barrett and Bartuska (1982), may have directly influenced cellular differentiation in the basal node region. This reaction is persistent throughout the production cycle following treatment. The stem collapse of poinsettia induced by paclobutrazol (Wilfret, 1981) may have resulted from poor development of secondary cell walls in structural supporting tissues, as observed in this study. While paclobutrazol has been shown to be a strong inhibitor of gibberellin biosynthesis (Hedden and Graebe, 1985), the histological implications of this effect have not been investigated.

Although all chemicals reduced poinsettia internode elongation as expected, it was also evident that they adversely affected normal fiber development in stems. This study confirms the previous reports of thinner walled cells and less extensively developed phloem fibers of various plant species by growthretarding chemicals. The newer triazole chemical retardants are effective at limiting stem lengths at very low dosage rates. A single foliar application of these triazoles at the rates tested is normally sufficient to achieve the desired finished height for potted AHDR poinsettias. It has not yet been determined whether multiple applications of paclobutrazol or uniconazole at even lower rates will provide the same degree of height control without the associated reduction or elimination of fiber wall development in stems of self-branching poinsettia cultivars.

\section{Literature Cited}

Banko, T.J. and M.A. Stefani. 1988. Growth response of selected container-grown bedding plants to paclobutrazol, uniconazole, and daminozide. J. Environ. Hort. 6:124-129.

Barrett, J.E. and C.A. Bartuska. 1982. PP333 effects on stem elongation dependent on site of application. HortScience 17:737-738.

Barrett, J.E., M.E. Peacock, and T.A. Nell. 1986. Height control of Exacum and Chrysanthemum with paclobutrazol, XE-1019, and RSW-04111. Proc. Fla. State Hort. Soc. 99:254-255.

Beneš, K. 1968. On stainability of plant cell walls with Alcian blue. Biol. Plantarum 10:335-346.

Cathey, H.M. and N.W. Stuart. 1961. Comparative plant growth-retarding activity of Amo1618, phosphon, and CCC. Bot. Gaz. 123:5157.

Crittendon, C.E. and D.C. Kiplinger. 1969. Effects of B-Nine and cycocel on some factors influencing leaf color and stem strength of chrysanthemum and poinsettia. Ohio Florists' Assn. Bul. 481:2-4

Gill, G.W., J.K. Frost, and K.A. Miller. 1974. A new formula for a half-oxidized hematoxylin solution that neither overstains nor requires differentiation. Acta Cytochem. 18:300-311.

Graham, E.T. 1988. A novel approach to sectioning refractory tissue. HortScience 23:735.

Greulach, V.A. and J.G. Haesloop. 1954. Some effects of maleic hydrazide on internode elon- gation, cell enlargement, and stem anatomy. Amer. J. Bot. 41:44-50.

Hedden, P. and J.E. Graebe. 1985. Inhibition of gibberellin biosynthesis by paclobutrazol in cellfree homogenates of Cucurbita maxima endosperm and Malus pumila embryos. J. Plant Growth Regulat. 4:111-112.

Jacquiot, M.C. 1953. Observations sur l'histogenèse et la Signification dans les culturesin vitro de tissue cambial de certains arbres forestièrs. Compt. Rend. Soc. Biol. 235:960-961.

Johansen, D.A. 1940. Plant microtechnique. McGraw-Hill, New York.

Larson, R.A. and R.J. Kimmins. 1972. Response of Chrysanthemum monfolium Ramat. to foliar and soil application of ancymidol. HortScience 7:192-193.

Larson, R.A., J.W. Love, D.L. Strider, R.K. Jones, J.R. Baker, and K.R. Horn. 1978. Commercial poinsettia production. North Carolina Agr. Ext. Serv. AG-108.

Lindstrom, R.S. and N.E. Tolbert. 1960. (2Chloroethyl)trimethyl-ammonium chloride and related compounds as plant growth substances. IV. Effect on chrysanthemums and poinsettias. Michigan State Univ. Agr. Expt. Sta. Quart. Bul. 42:917-928.

Mansour, H.A. and R.T. Poole. 1987. Trials with growth retardants on ornamental plants. Proc. Fla. State Hort. Soc. 100:375-378.

McConnell, D.B. and B.E. Struckmeyer. 1971. The effects of succinic acid 2,2-dimethyl hydrazide on the anatomy of Tagetes erecta L. J. Amer. Soc. Hort. Sci. 96:70-73.

McDaniel, G.L. 1986. Comparison of paclobutrazol, flurprimidol, and tetcyclacis for controlling poinsettia height. HortSciencc 21:1161-1163.

O'Brien, T.P. and M.E. McCully. 1981. The study of plant structure, principles and selected methods. Termacarphi Pty., Victoria, Australia.

Sachs, R.M. and A.M. Kofranek. 1963. Comparative cytohistological studies on inhibition and promotion of stem growth in Chrysanthemum morifolilum. Amer. J. Bot. 50:772-779.

Sachs, R.M., A. Lang, C.F. Bretz, and J. Roach. 1960. Shoot histogenesis-Subapical meristematic activity in a caulescent plant and the action of gibberellic acid and AMO-1618. Amer. J. Bot. 47:260-266.

Shafshak, S.E., A.H. Shahine, and A.S. El-Dababy. 1976. Effects of nitrogen fertilizer level and two growth retardants on the anatomy and fiber quality of cotton plant(Gossypium barbadense L.). Z. Acker-und Pflanzenbau 142:275284.

Sterrett, J.P. 1988. XE-1019: Plant response, translocation, and metabolism. J. Plant Growth Regulat. 7:19-26.

Wilfret, G.J. 1981. Height retardation of poinsettia with ICI-PP-333. HortScience 16:443. 